Article

\title{
Adaptation Strategies and Resilience to Climate Change of Historic Dwellings
}

\section{Carlos Rubio-Bellido ${ }^{1, *}$, Jesus A. Pulido-Arcas ${ }^{2}$ and Jose M. Cabeza-Lainez ${ }^{3}$}

1 Higher Technical School of Building Engineering, Universidad de Sevilla, Seville 41012, Spain

2 Canon Foundation, Amstelveen 1180, The Netherlands; E-Mail: jesus.a.pulido@gmail.com

3 Faculty of Science, Hokkaido University, Sapporo, Hokkaido 060-0808, Japan;

E-Mail:wspole@gmail.com

* Author to whom correspondence should be addressed; E-Mail: carlosrubio@us.es;

Tel.: +34-686-135-595.

Academic Editor: Rafael D’Almeida Martins

Received: 4 February 2015 / Accepted: 24 March 2015 / Published: 30 March 2015

\begin{abstract}
Historic city centres have a large amount of dwellings in Europe, which were built to provide a comfortable shelter with the absence of mechanical means. The knowledge of climate responsive design strategies can play a significant role in reducing the energy demand of extant buildings, paving the way for its sustainable development in the face of the rising threat to its occupants of climate change. The residential architecture, developed, in most cases, in dense urban centres, was built using both available materials and traditional and academic construction technologies. This paper thoroughly investigates the extant urban conglomerate in Cádiz and analyses, in a qualitative and quantitative manner, which bioclimatic design strategies were applied and the city's adaptation for future climate scenarios. The results indicate that historic housing in Cádiz is creatively adapted to the local natural conditions by means of a combination of climate responsive strategies, and there is significant scope for improvement in the ongoing response to global warming.
\end{abstract}

Keywords: climate responsive building design; climate change mitigation; historic architecture; traditional building techniques; bioclimatic design 


\section{Introduction}

In recent years, climate change poses a severe threat to human settlements and building performance [1]. The depletion of energy resources and the risk of global warming are calling for sustainable development in the building sector based on renewable energies and energy efficiency [2]. Most of the current research in this area is focused on extant cities [3] and their architecture [4] in order to evaluate their resilience for future scenarios through a holistic approach. The propensity for higher indoor temperatures not only affects the building performance but also human health. Therefore, several strategies for climate change adaptation [5] have been set in buildings in order to achieve comfort to their occupants.

It is generally acknowledged that the building sector accounts for about one-third of the total energy consumption worldwide. This sector in Europe, including households and services, assumes 37.4\% of total energy consumption with indications that this could increase in the next few years [6]. For 2020, the Spain National Energy Plan predicts that $15.6 \%$ of the overall reduction in energy savings will be accounted for by the construction sector [7]. Most climatic models point to a substantial future change in climate of approximately $+1.5{ }^{\circ} \mathrm{C}$ in annual mean temperature by 2050 and $+2-4{ }^{\circ} \mathrm{C}$ by 2080 [8]. The models also indicate that the annual mean temperature difference between London and the northern Mediterranean coast around Nice is only $5{ }^{\circ} \mathrm{C}$ [9]. It is therefore clear that the effect is not a minor one and that the implications for existing buildings are likely to be large. For this reason, it is essential to understand the behaviour of a large part of the building stock and its resilience for future climate scenarios.

From a building point of view, these effects represent specific gradual changes. For instance, a slight rise in average ambient temperature has consequences for comfort as experienced by occupants and energy consumption. This local viewpoint strengthens the need to change the focus from a generic idea of "climate" to specific local weather conditions. While global forecasts might be reasonably accurate, predicting local environmental effects is more difficult: the higher resolution that is needed to create local predictions is bought at the price of higher uncertainties [10].

The scarcity of natural resources optimized the climate adaptation of historic architecture through the use of local materials [11,12]. Several studies have proven that energy savings and thermal performance can be achieved by means of traditional architecture [13-15], but it is crucial to also analyse its resilience against future climatic conditions.

\section{Objectives and Methodology}

This research aims at elucidating the climate responsive strategies of the historic dwellings of the city of Cádiz in terms of comfort conditions for their occupants and its scope for improvement in future scenarios. The necessity to document this knowledge "learning from the past" [16-18] in a specific case-study strengthens the understanding of the sustainable design strategies that were considered in local climate conditions in order to provide comfort, whilst preparing for climate variation in future decades.

The methodology of this research uses fieldwork in order to obtain firsthand data of the analysed historic architecture. Statistical treatment of results led to the identification of the main morphological 
and constructive features of these houses. Climate responsive design strategies adapted to this location area were devised using computer calculation tools. Field monitoring of environmental variables provided on-site data about the environmental performance of selected buildings. Comparison of design strategies and on-site monitoring provided the research with the necessary feedback in order to clarify the main climate responsive design strategies for these buildings.

The fieldwork was conducted from January 2009 to November 2009 for the assessment of the heritage properties in the old quarter of Cádiz. Eighty-eight residential properties were assessed during 10 months. As a result of this work, a wide database was compiled, which included information about house morphology, constructive systems, historical records and graphical information (plans, historical drawings and photographs). Data mining, in turn, provided researchers with the predominant house typology.

Using this database, this research analyses the historic dwellings in Cádiz, with respect to their morphological characteristics and constructive systems in order to determine the elements through which climate responsive design strategies are tackled. The study uses a set of building features to analyse the design and construction techniques of the historic dwellings with regard to climate-responsiveness. The following features have been identified as the most valuable in order to assess the historic housing of Cádiz in a qualitative manner: building morphology, solar access, and design and construction of the thermal enclosure (walls, roof, ceilings and openings).

The research identifies the dominating bioclimatic design strategies applied in the historic architecture to achieve comfort. The study of comfort as a measurable psycho-physical parameter is based on Olgyay and Givoni studies, which are a starting point on which several models have settled $[19,20]$. The prediction of comfortable temperature for naturally ventilated buildings is usually based on an "adaptive approach", which is the outcome of the field studies and is part of the ASHRAE (American Society of Heating, Refrigerating, and Air-Conditioning Engineers) standard 55/2013 [21]. However, in order to understand the climate responsive strategies applied a model that considers climate parameters, building features and adaptation by people is needed. The comfort model selected is defined in the 2005 ASHRAE Handbook of Fundamentals [22], which takes into account the aforementioned variables. Both models run in Climate Consultant, a tool developed by the UCLA Energy Design Tools Group [23], which uses Energy Plus Weather Data (EPW) files [24] for each location. This type of file for the specific case of Cádiz has records of hourly values during a year, which is a thorough approximation and allows us to establish a hypothesis for future increases in temperature.

Long-term monitoring work has been accomplished in order to verify the internal environmental conditions of buildings in a quantitative manner. The monitoring process includes the measurements of temperature (indoors) for 10 days in the summer and winter of the year 2011 through data loggers (HOBO RH/Temp/Light/External Data Logger, Austin, TX, USA). The temperature sensor accuracy is $\pm 0.7^{\circ} \mathrm{C}$ and the humidity sensor accuracy is $\pm 5.0 \% \mathrm{RH}$, respectively.

This research compares generic climate responsive design strategies extracted from computer tools and on-site measurements for the main morphologic and constructive characteristics of the extant heritage dwellings of Cádiz. The adaptation of this architecture to the local climate conditions allows us to develop strategies for sustainable development. 


\section{The Case Study: The City of Cádiz}

\subsection{Location and History}

The city of Cádiz is in the south of Spain $\left(36^{\circ} 32^{\prime} \mathrm{N}, 6^{\circ} 18^{\prime} \mathrm{W}\right)$ and is largely surrounded by sea (Figure 1). When analysing the origin, formation and evolution of the city, the importance of its geographic and climatic conditions stand out. It is a separate, firmly closed, easily defended enclave, (thanks to a calm sea in the bay capable of providing a haven for entire fleets), and hostile waters to seaward. The land occupied by the historic centre today is a rocky platform in the shape of an irregular pentagon of about 140 hectares. It has been of great interest in history as a centre of commercial exchange and as a military enclave [25], two closely related activities. This area has seen various successive cultures such as the Phoenicians, Greeks, Carthaginians, and Romans [26]. The ancient city is a compact urban coherence of about 39,801 inhabitants at present, having been much more populated in recent times.

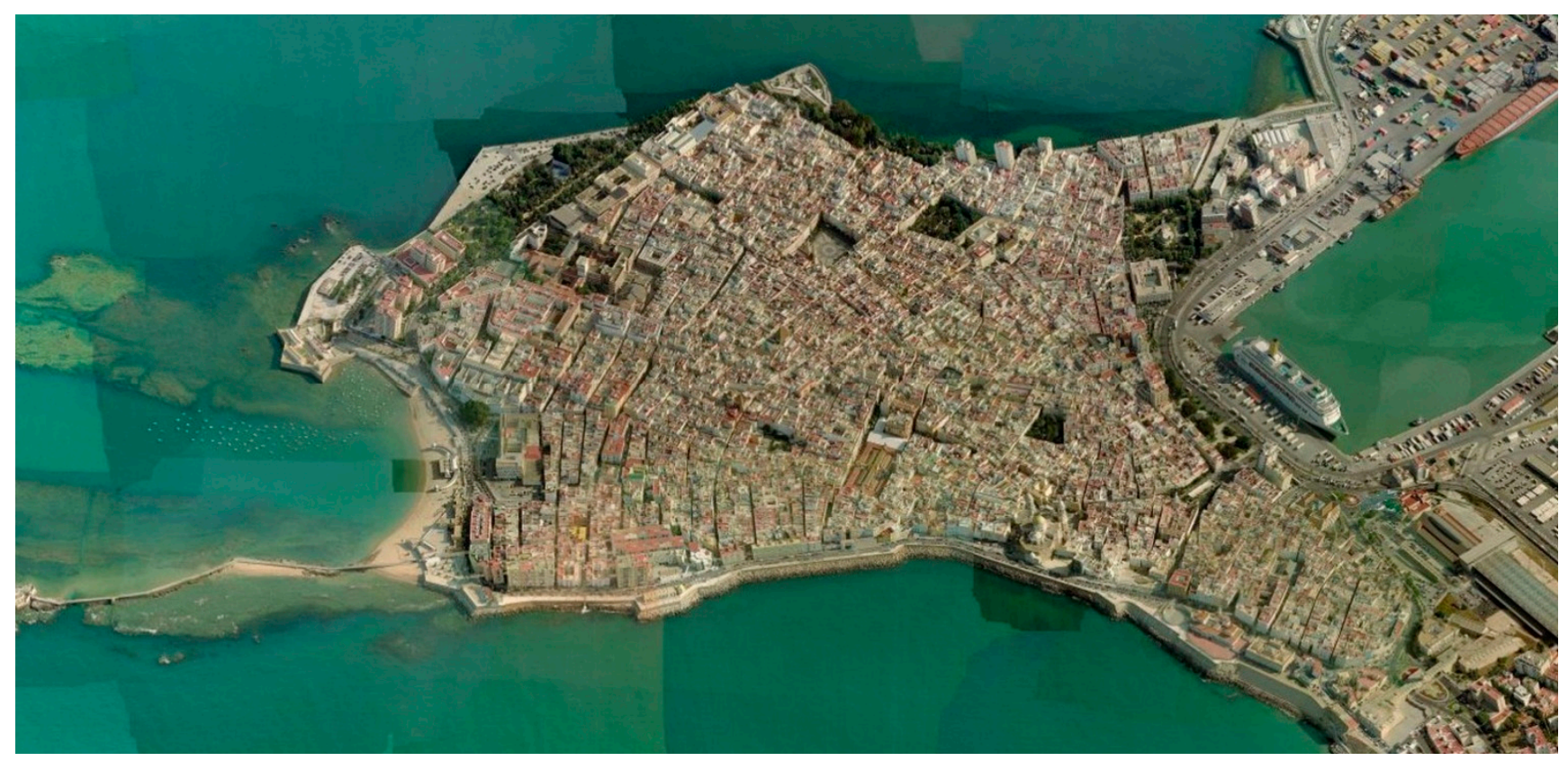

Figure 1. Aerial view of the historic city of Cádiz.

\subsection{Climate Analysis}

According to monthly normal parameters (Table 1), its climate is characterized by mild temperatures (mean $17.5^{\circ} \mathrm{C}$ ) with a relevant amount of sunshine hours $(2802 \mathrm{~h}$ per year), high relative humidity $(73 \%)$ and a constant regime of breezes $(\mathrm{v}<4 \mathrm{~m} / \mathrm{s})$ with only a few calm days. It is a mild Mediterranean climate [27] due to its coastal location. The summers are fairly mild and the winters are not severely harsh with scarce precipitation. This favourable scenario foretells the feasibility of achieving comfort conditions through natural methods [28]. 
Table 1. Monthly normal climate of Cádiz [29].

\begin{tabular}{cccccccccccccc}
\hline Months & & Jan. & Feb. & Mar. & Apr. & May & June & July & Aug. & Sept. & Oct. & Nov. & Dec. \\
\hline & Max. & 15.6 & 16.4 & 18.2 & 19.3 & 21.7 & 24.9 & 28.1 & 28.5 & 26.4 & 22.6 & 19.0 & 16.6 \\
Temp. $\left({ }^{\circ} \mathrm{C}\right)$ & Min. & 8.4 & 9.1 & 10.1 & 11.3 & 13.6 & 16.4 & 18.8 & 19.3 & 18.0 & 15.1 & 11.8 & 9.9 \\
& Med. & 12.1 & 12.7 & 14.2 & 15.3 & 17.7 & 20.6 & 23.5 & 23.9 & 22.2 & 18.9 & 15.4 & 13.2 \\
Rainfall $(\mathrm{mm})$ & & 86.0 & 66.5 & 51.0 & 57.5 & 34.0 & 11.0 & 2.0 & 5.0 & 18.0 & 67.0 & 81.5 & 113.5 \\
Rainy days $\left(\mathrm{n}^{\circ}\right)$ & & 8 & 8 & 6 & 7 & 4 & 2 & 0 & 0 & 2 & 6 & 7 & 10 \\
RH $(\%)$ & & 77.5 & 76.5 & 72.5 & 71.5 & 70.5 & 69.5 & 67.5 & 69.0 & 71.5 & 75.0 & 76.5 & 78.0 \\
Sun. hours (h) & 167 & 171 & 216 & 231 & 281 & 297 & 330 & 317 & 246 & 215 & 179 & 152 \\
\hline
\end{tabular}

\subsection{Architecture and Urban Grid}

The majority of the surviving traditional architecture of Cádiz was erected from the 17th century to the 19th century since the primitive city was consistently reformed by the boom of the commercial harbour. Such urban tissue derived from vernacular traces and alien influences which flowed to a hub of rich trade in commodities and ideas.

The extant urban conglomerate can be identified as compact with labyrinthine streets and courtyards (Figure 2a). Life in Cádiz is notoriously influenced by outdoor conditions; in fact, the town possesses a tradition for intuitive building methods adapted to the climate. Its architecture (Figure 2b) can be compared to other Mediterranean enclaves like Ortigia in Siracusa or the Spanish Quarters in Naples (Quartieri Spagnoli).

As general features of this urban grid were identified in the fieldwork, the predominance of vertical openings in façades, the use of central courtyards to organise and register the living space, and the variegated elements for solar control like shutters, blinds and louvers could be outlined. Solar control elements are so complex that they often project from the façades.

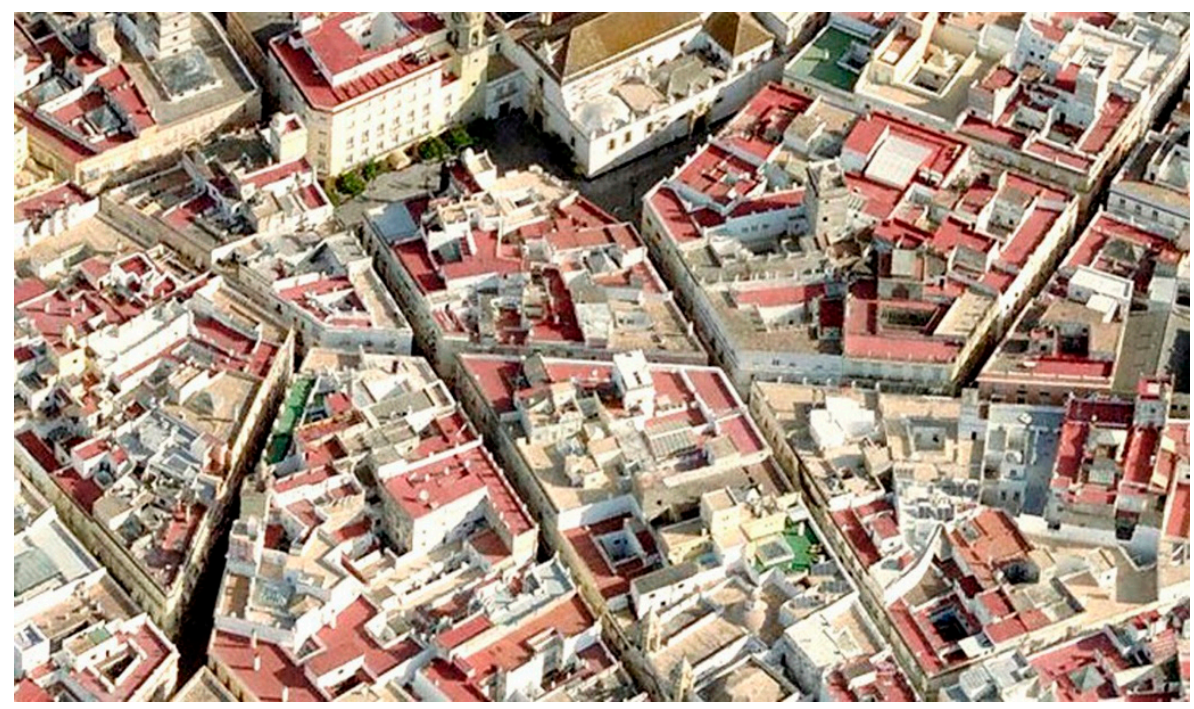

(a)

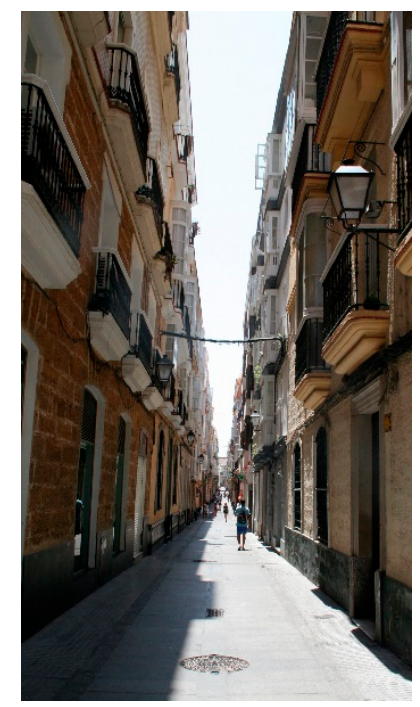

(b)

Figure 2. (a) Aerial view of the historic urban grid; (b) Typical street. 


\section{Climate Sensitive Design in Historic Dwellings}

\subsection{Morphology of the Building and Solar Access}

Based on the field work, the prevalent type of dwelling could be established (Figure 3a,b): row-houses which hark back to the seventeenth century, organized around a courtyard, of varying dimensions [30]. Although the courtyards' proportions look relatively narrow, they are usually wider than the adjacent streets. Such confined alleys seep inside the urban structure. The building heights are usually set at four storeys and this contributes to a uniform image on the street front. Except for a few singular plots located around public squares, the majority of buildings respond to the said disposition.

As well as other historical quarters, which present great compactness and shading in sunny climates, the access to solar radiation in the urban grid plays a key role in the environmental performance on this architecture [31-33]. In addition to the direct and diffuse radiation components modified due to the geometry of the obstructions involved, the reflected component and the radiant exchange have been defined in previous studies of the authors $[34,35]$ in order to clarify heat flux and solar gains.

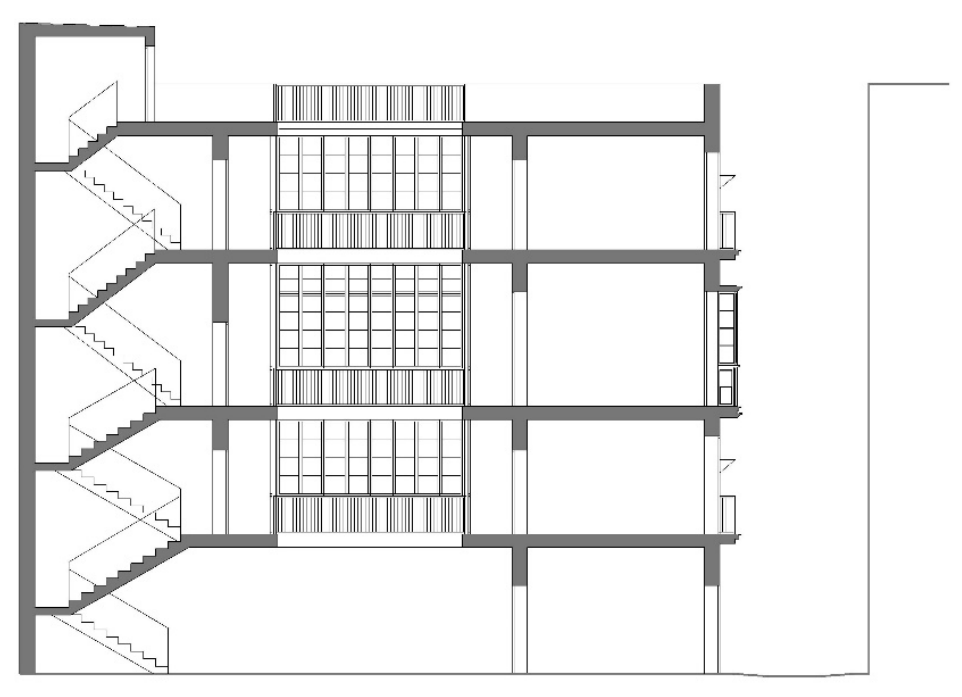

(a)

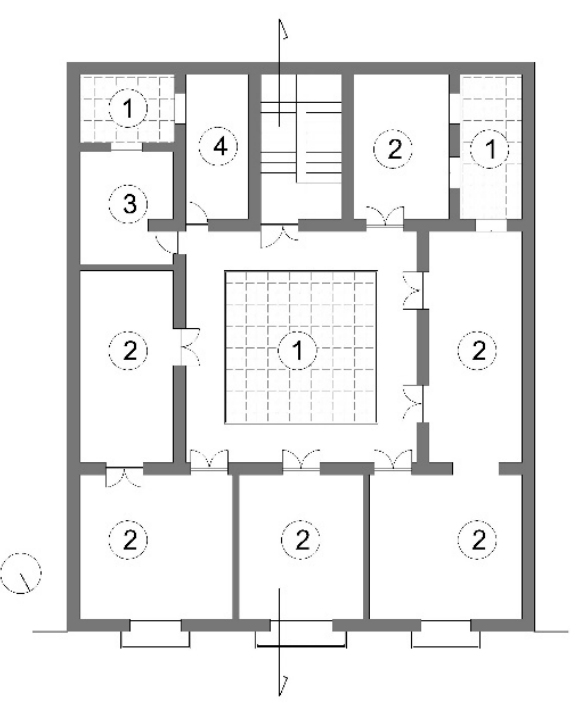

(b)

Figure 3. (a) Section of typical dwelling; (b) Plan. 1. Courtyard; 2. Room; 3. Kitchen; 4. Bathroom.

\subsection{Envelope}

\subsubsection{Walls}

The walls of historic Cádiz houses are mostly made of "ostionera" stone, a very porous sedimentary rock formed by the remains of seashells used in the bay area. The thickness ranges between $60 \mathrm{~cm}$ and $50 \mathrm{~cm}$ at the ground and first floor, executed traditionally as Ashlar and finished with lime mortar. To a lesser extent, ostionera stone appears exposed to the air as a socket way. The second storey of certain buildings are made of ostionera stone masonry, and, in other properties, especially in buildings from the 18th and 19th centuries, these are made of masonry or solid brick $(30 \mathrm{~cm} \times 15 \mathrm{~cm} \times 5 \mathrm{~cm})$, decreasing its thickness. The third storeys are mostly made of solid brick. The second and the third 
storeys are coated with lime mortar. The colour of the walls are usually light-toned mixing the lime with clay, in a wide variety of tones.

Besides U value [36], walls are mainly characterised by long thermal lags and high values for thermal damping [37,38] (Table 2). The ashlar walls range from 14.00 to $18.67 \mathrm{~h}$, which involves more than half a day, causing the solar radiation on the outside of the walls to not have an immediate effect on the inside; thermal wave damping is between $99 \%$ and $97 \%$ in walls of ashlar, giving, as a result, an attenuation of the energy transferred to the inner side of the wall. These two effects combined keep the temperature on the inside of the wall very stable. As thermal mass is reduced in the upper storeys, the thermal lag is reduced to $9.34 \mathrm{~h}$ and thermal wave damping to $91 \%$. These upper floors, located in the top of the urban canyon, are likely to receive more radiation than the lower floors due to solar access and reflections, so they are exposed to a greater thermal oscillation on the outside. However, the values of damping and lag are still significant. In the case of solid brick walls, used on upper storeys, similar values of damping and lag of the thermal wavelength can be found, due to the nature of the material. Hence, thermal inertia also plays an important role [39]. These high values of thermal inertia allow greater thermal stability, which, in principle, would be a desirable feature, especially in climates with temperature ranges close to comfort.

Table 2. Main thermal and constructive parameters of the walls.

\begin{tabular}{ccccccccc}
\hline \multirow{2}{*}{ Wall types } & Thickness & $\mathbf{U}$ value & Density & Conductivity & Diffusivity & Effusivity & Lag & Damp \\
\cline { 2 - 9 } & $\mathbf{m}$ & $\mathbf{W} / \mathbf{m}^{\mathbf{2}} \mathbf{K}$ & $\mathbf{k g} / \mathbf{m}^{\mathbf{3}}$ & $\mathbf{W} / \mathbf{m} \mathbf{~ K}$ & $\mathbf{m}^{\mathbf{2}} / \mathbf{s} \mathbf{1 0}^{-\mathbf{6}}$ & $\mathbf{s}^{\mathbf{1 / 2}} \mathbf{W} / \mathbf{m}^{\mathbf{2}} \mathbf{K}$ & $\mathbf{h}$ & $\mathbf{0}-\mathbf{1}$ \\
\hline \multirow{3}{*}{ Ostionera } & 0.60 & 0.73 & 1000 & 0.55 & 0.55 & 742 & 18.67 & 0.99 \\
ashlar & 0.55 & 0.79 & 1000 & 0.55 & 0.55 & 742 & 17.12 & 0.99 \\
& 0.50 & 0.85 & 1000 & 0.55 & 0.55 & 742 & 15.56 & 0.98 \\
& 0.45 & 0.92 & 1000 & 0.55 & 0.55 & 742 & 14.00 & 0.97 \\
\hline \multirow{2}{*}{ Ostionera } & 0.40 & 1.00 & 1000 & 0.55 & 0.55 & 742 & 12.45 & 0.96 \\
masonry & 0.35 & 1.10 & 1000 & 0.55 & 0.55 & 742 & 10.89 & 0.94 \\
& 0.30 & 1.23 & 1000 & 0.55 & 0.55 & 742 & 9.34 & 0.91 \\
\hline \multirow{2}{*}{ Solid brick } & 0.30 & 1.61 & 2300 & 0.85 & 0.37 & 1398 & 11.39 & 0.95 \\
& 0.15 & 2.24 & 2300 & 0.85 & 0.37 & 1398 & 5.69 & 0.77 \\
\hline \multirow{2}{*}{} & & & & & & & &
\end{tabular}

\subsubsection{Roofs}

The flat roof is the generic formula in Cádiz architecture. The traditional building system is supported by the structure of the last floor and it is composed of various layers. From the inside to the outside constructive system features first, a waterproofing layer made of clay and lime mixture, laid over the bricks. Located over it is a layer of soot, which acts as lightener. After that, another layer of clay and lime is featured. Finally, the ceramic tiles are built over a lime mortar layer.

Most roofs are at the same height, which produce a lack of significant solar obstructions, but only their own parapets and some specific elements, such as the turrets that are still preserved, block solar radiation. Despite the fact that they are the elements of the building that receive greater amounts of solar radiation, flat roof thermal lags (Table 3) are about $8.87 \mathrm{~h}$ and the wave damping is $91 \%$, so their performance is similar to the walls. This thermal inertia and stability provides a tight range of indoor temperatures. 
Table 3. Main thermal and constructive parameters of the roof.

\begin{tabular}{ccccccccc}
\hline \multirow{2}{*}{ Layers } & Thickness & $\mathbf{U}$ value & Density & Conductivity & Diffusivity & Effusivity & Lag & Damp \\
\cline { 2 - 8 } & $\mathbf{m}$ & $\mathbf{W} / \mathbf{m}^{\mathbf{2}} \mathbf{K}$ & $\mathbf{k g} / \mathbf{m}^{\mathbf{3}}$ & $\mathbf{W} / \mathbf{m ~ K}$ & $\mathbf{m} \mathbf{2} / \mathbf{~ 1 0}^{-\mathbf{6}}$ & $\mathbf{s}^{\mathbf{1} / \mathbf{2}} \mathbf{~ W / \mathbf { m } ^ { \mathbf { 2 } } \mathbf { K }}$ & $\mathbf{h}$ & $\mathbf{0 - 1}$ \\
\hline Ceramic tiles & 0.01 & & 2000 & 1.00 & 0.63 & 1265 & 0.29 & \\
Lime mortar & 0.02 & & 1250 & 0.70 & 0.56 & 935 & 0.62 & \\
Clay mortar & 0.02 & & 500 & 1.10 & 2.20 & 742 & 0.31 & \\
Soot & 0.15 & & 450 & 1.00 & 2.22 & 671 & 2.32 & \\
Clay mortar & 0.20 & & 500 & 1.10 & 2.20 & 742 & 3.11 & \\
Solid brick & 0.03 & & 2300 & 0.85 & 0.37 & 1398 & 1.14 & \\
Wood batten & 0.02 & & 610 & 0.18 & 0.18 & 419 & 1.07 & \\
Total & 0.45 & 1.48 & & & & & 8.87 & 0.91 \\
\hline
\end{tabular}

\subsection{Openings}

\subsubsection{Balconies}

Balconies are one of the characteristic elements of the buildings, as well as part of the iconic images of the city. Except for the ground floor, they are present on all levels of the façades (Figure 4c). This opening is much more frequent than with the windows, which can be identified only in scarce locations and always on the last storey. They usually feature $1.00-1.20 \mathrm{~m}$ width by $2.20-2.40 \mathrm{~m}$ in height.

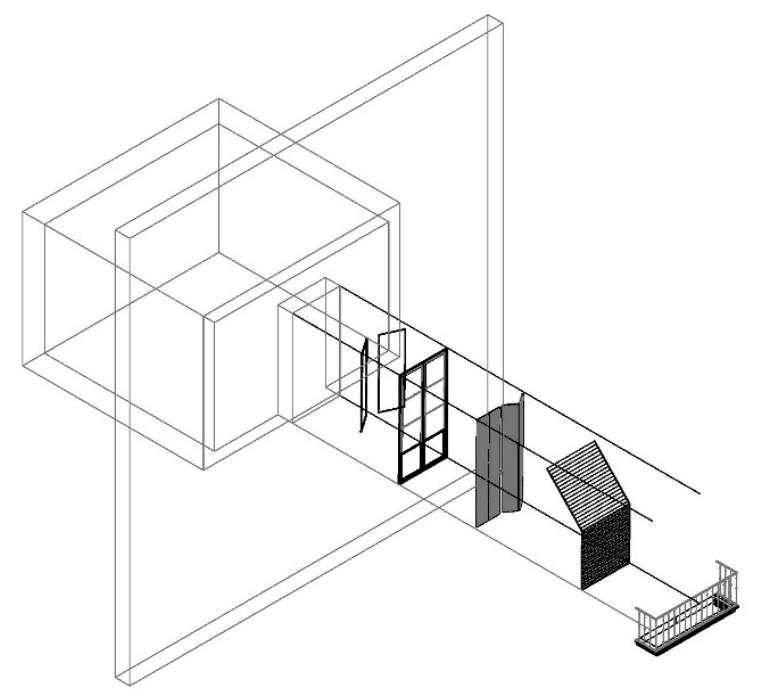

(a)

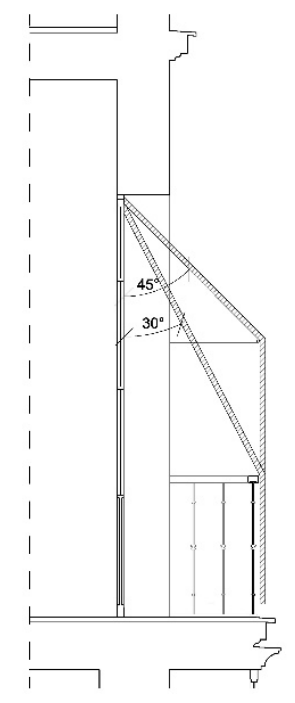

(b)

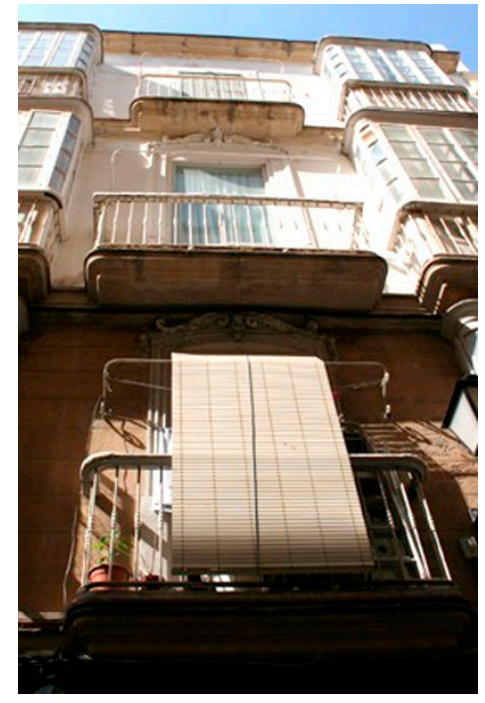

(c)

Figure 4. (a) Balcony layers; (b) Example of the roller blind positions. (c) Balconies in various levels.

The balcony is an opening with various elements distributed from the outside to the inside of the following way (Figure 4a,c): exterior roller blinds and adjustable shutters, hinged windows, net curtains, interior hinged shutters and curtains. Therefore, it is a complex filter formed by the by the addition of elements, with a large number of combinations in order to adapt to the changing outdoor conditions (Figure 4b). By all possible aggregations of these protections, diverse coefficients of thermal transmittance [40] and modified solar factor [41] are obtained, which can impede or enhance 
the heat transmission through the opening (Table 4). They also serve as interceptors of the impinging solar radiation, with the consequent reduction of the solar gains on the glazed openings.

Table 4. Main thermal properties of the balconies.

\begin{tabular}{cccccc}
\hline & \multicolumn{3}{c}{ Exterior layer } & Interior layer \\
\hline & $\begin{array}{c}\text { Hinged } \\
\text { window }\end{array}$ & $\begin{array}{c}\text { Hw }+ \\
\text { adjustable shutter }\end{array}$ & $\begin{array}{c}\text { Hw }+ \\
\text { roller blind 30 }\end{array}$ & $\begin{array}{c}\text { Hw }+ \\
\text { roller blind 45 }\end{array}$ & $\begin{array}{c}\text { Hw }+ \\
\text { hinged shutter }\end{array}$ \\
\hline $\mathrm{U}$ value $\mathrm{W} / \mathrm{m}^{2} \mathrm{~K}$ & 3.73 & 2.87 & 3.73 & 3.73 & 2.05 \\
Modified solar factor & 0.37 & 0.06 & 0.12 & 0.14 & 0.37 \\
\hline
\end{tabular}

\subsubsection{Glazed Balconies}

This type of opening is adopted in the city especially in the Isabelino style. The complex frame protruding over the railing is inserted on the balcony itself. Its design and treatment are unique and cannot be found in other nearby locations of their counterpart cities in southern Spain. Despite the U value being $2.11 \mathrm{~W} / \mathrm{m}^{2} \mathrm{~K}$, its environmental performance in this case is different than a double glazed opening, since it also involves heat accumulation in the intermediate space (the gallery), which, in turn, has an effect on the thermal inertia of the wall (Figure 5a). On the inner side of the simple glazing, net curtains are usually attached. In order to delimitate the interior space of the room, dense wooden doors are opened during the day. As a rule, glazed balconies are very advantageous in energy issues such as with attached greenhouses creating air chambers, which decrease the conduction of thermal losses, thus creating comfort when outside temperatures do not fall abruptly. It also represents a natural heat accumulator in winter, due to the transmission of long wavelength radiation through the opening or through the wall, using its thermal inertia. In summer, openings avoid overheating and enjoy enhanced natural ventilation (Figure 5b).

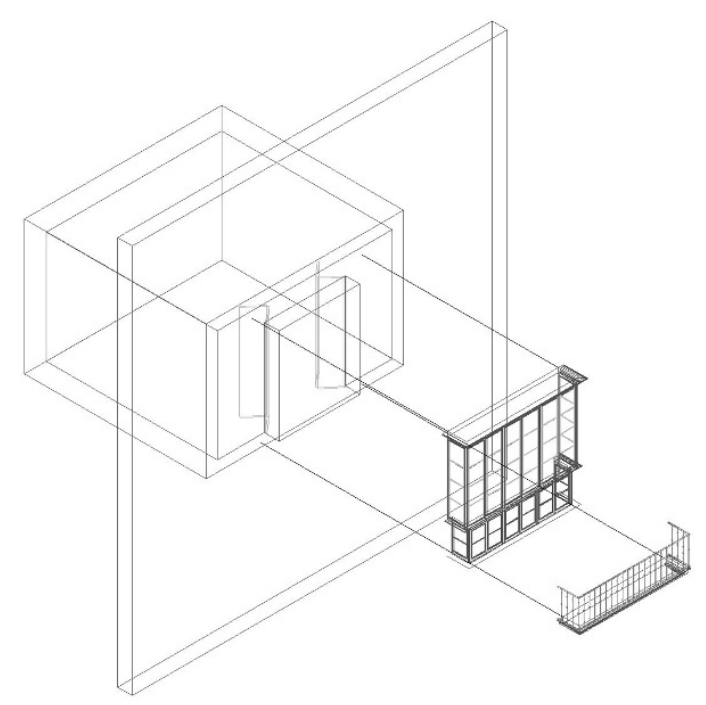

(a)

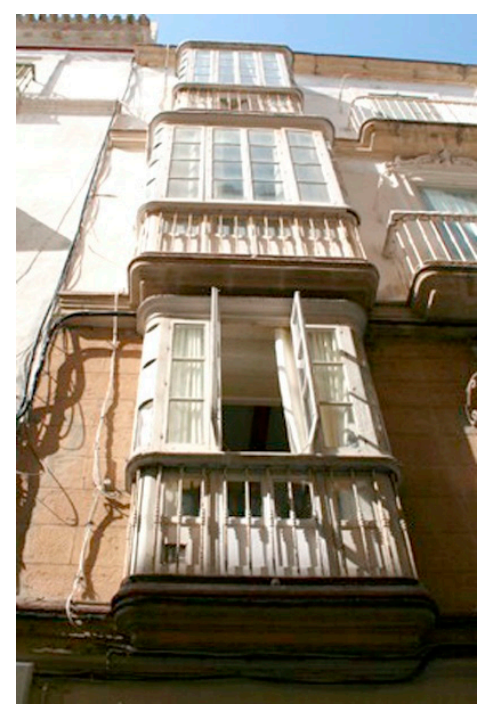

(b)

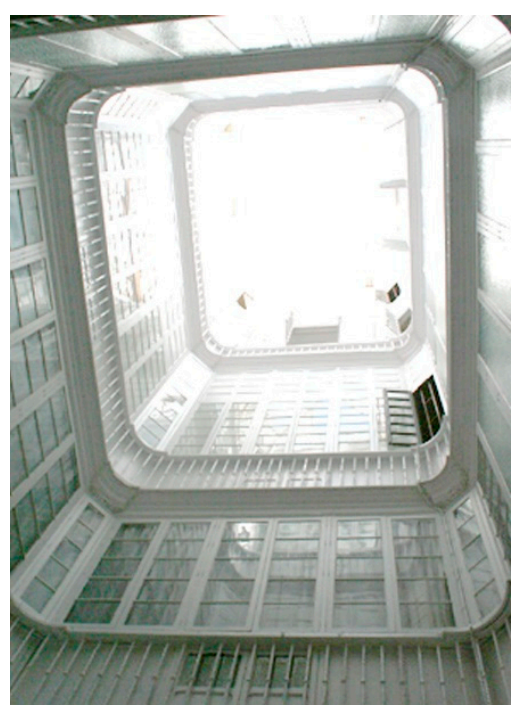

(c)

Figure 5. (a) Glazed balcony layers; (b) Glazed balconies in various levels; (c) Courtyard. 


\subsubsection{Courtyards}

Inner courtyards in the old houses of Cádiz are characterized broadly by their narrow proportions, so that they can be described as "deep courtyards" (Figure 5c). The average dimensions are $5.00 \mathrm{~m}$ with a height determined by their own buildings ( $15.50 \mathrm{~m}$ on average). They are usually located after the first bay in all plots, that is, $4.50 \mathrm{~m}$ from the main façade. These dimensions and positions are a consequence of the homogeneity in construction systems; although, there are exceptions in various representative buildings, our field work gives support to this predominant inner void of space. Simple glazing in courtyards is introduced due to the lack of privacy in the division of the property in apartments. It is mostly made with pine frames and painted white.

Conceived as a search for lighting and ventilation in dense urban plots [42], these confined spaces are less exposed to the prevailing winds. In summer conditions, they tend to be cooler than the outdoors, since their features cool down the air overnight by wavelength long radiation and ventilation [43]. During the day they are protected from solar gains through awnings, cooling the interior rooms through the previously stored air during the night, which can also be naturally conditioned by water and vegetation providing evaporative cooling. In winter conditions, courtyards are able to achieve heat gains, distributing them to the interior space [44].

\section{Climate-Responsive Design Strategies Applied}

\subsection{Adaptive Comfort Model}

Adaptive Comfort model is defined in ASHRAE Standard 55 [21], which it applies in naturally ventilated spaces where people can open and close windows. Indoor conditions are acceptable when average outdoor air temperatures are between $10^{\circ} \mathrm{C}$ and $33.5^{\circ} \mathrm{C}$, and when indoor temperatures can be held within a specified 10 degree indoor operative temperature range. In the case of the specific climate of Cádiz, in the $80 \%$ range of acceptable limits, the minimum and maximum mean monthly outdoor dry bulb temperature is $12.4{ }^{\circ} \mathrm{C}$ and $24.7{ }^{\circ} \mathrm{C}$, and the comfort low and high operative temperature in this climate are $18.1^{\circ} \mathrm{C}$ and $29.0^{\circ} \mathrm{C}$. This is a suitable method to identify adaptations to local climate and future temperature measurements [45], depending on outdoor conditions. It assumes that people will adapt their clothing to the climate $(1.0$ to $0.5 \mathrm{Clo})$, and that they are engaged in sedentary activities such as reading (1.0 to 1.1 Met). The Standard does not discuss how adaptive comfort is affected by the other building design strategies. Thus, comfort is defined only in terms of adaptive comfort using natural ventilation.

Taking into account the considerations above, comfort using natural ventilation is achieved $31.1 \%$ of the year (Table 5), $2722 \mathrm{~h}$ of the 8760 hourly data from the year. In the monthly data, these values are currently increased in the summer months of July, August and September to above 70\%, which considerably decreases in future scenarios in the case of major warming. During the winter months, this strategy can hardly provide any comfort conditions. In the future, the measurument of mean and low operative temperature comfort conditions during these seasons will be improved. 
Table 5. Adaptive Comfort Model in ASHRAE Standard 55-2013 applied to Cádiz.

\begin{tabular}{cccccccccccccc}
\hline & Annual & Jan. & Feb. & Mar. & Apr. & May & June & July & Aug. & Sep. & Oct. & Nov. & Dec. \\
\hline Comfort \% & 31.1 & 0.7 & 0.9 & 8.5 & 10.8 & 27.2 & 51.8 & 71.0 & 74.6 & 70.6 & 41.4 & 11.8 & 1.7 \\
Comfort hours & 2722 & 5 & 6 & 63 & 78 & 202 & 303 & 528 & 555 & 508 & 306 & 85 & 13 \\
Total hours & 8760 & 744 & 672 & 744 & 720 & 744 & 720 & 744 & 744 & 720 & 744 & 720 & 744 \\
\hline
\end{tabular}

\subsection{ASHRAE Handbook of Fundamentals Comfort Model}

The comfort model defined in the 2005 ASHRAE Handbook of Fundamentals [22] considers the variability of the comfort zone according to apparel (1.0 Clo in winter and 0.5 in summer), therefore the warmer zone correlates with people wearing lighter summer clothes. The temperatures are defined by slightly sloped lines that account for the effect of humidity on comfort. For people dressed in normal winter clothes, effective temperatures of $20{ }^{\circ} \mathrm{C}$ to $23.3{ }^{\circ} \mathrm{C}$ were measured at $50 \%$ relative humidity. The upper humidity limit is $17.8^{\circ} \mathrm{C}$ (Wet Bulb temp.) and a lower dew point of $2.2^{\circ} \mathrm{C}$. If people are dressed in lightweight summer clothes, this comfort zone shifts $2.8^{\circ} \mathrm{C}$ warmer. This model takes into account sedentary activities as well as the adaptive model (1.0 to $1.1 \mathrm{Met})$ but also includes various strategies applied to achieve comfort.

The mild climate of the city of Cádiz has resulted in a strengthening of the natural environmental conditioning techniques. These have materialised in environmental control (roofs, façades, courtyards and balconies) elements known to the entire population and accepted as part of their culture and their ethnology. With regards to the characteristics of these existing elements, several climate responsive strategies are applied including sun shading of windows, high thermal mass, high thermal mass night flushed, direct evaporative cooling, natural ventilation cooling, internal heat gain, passive solar direct gain low mass and passive solar direct gain high mass.

A combination of these strategies can achieve comfort levels for $87.7 \%$ of the year in the current situation (7686 of the 8760 h) (Figure 6). Comfort levels without applying any design strategy are reduced to $29.5 \%$, compared to $31.1 \%$ that was obtained with the Adaptive Comfort Model. A small deviation is justified by the fact that this model considers the global horizontal solar radiation and the relative humidity, which are decisive in this climate. Applying the strategy of sun shading of windows and passive solar direct gain through low mass (2 and 10), with regard to the openings, $11.1 \%$ and $13.3 \%$ of annual comfort is achieved. Complex systems of protection and solar gain in openings and courtyards and a compact urban fabric that controls the direct solar radiation play a significant role in comfort conditions. The high thermal mass of building envelope flushes heat during the nighttime and receives solar radiation during the day $(3,4,11)$ providing $2.7 \%, 3.5 \%$ and $17.0 \%$ of the annual comfort. This data foretells the feasibility of the building mass construction in this climate. Evaporative cooling (5) and (7) natural ventilation account for $2.5 \%$ and $6.9 \%$ of the annual comfort rate, respectively. Even though they have no influence on comfort unlike other strategies, it is crucial to employ them in order to avert possible overheating. The most representative strategy is internal heat gain (9); for merely inhabiting dwellings, $46.5 \%$ comfort is achieved. 


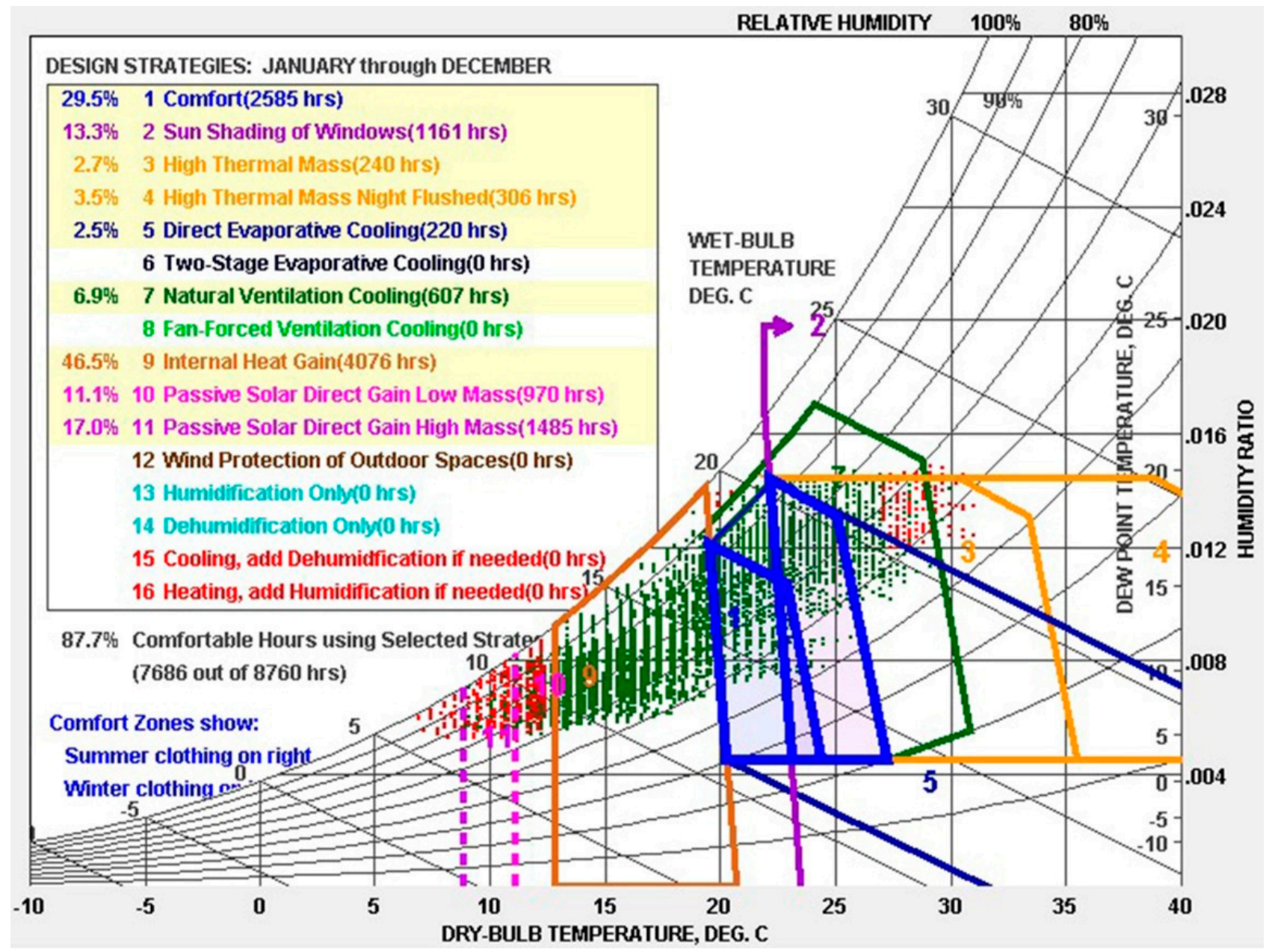

Figure 6. Psychometric chart with climate responsive strategies applied. Climate Consultant tool [20].

Categorizing these strategies by seasons (Table 6), comfort conditions can be achieved during $74.9 \%$ of the time in winter, $99.4 \%$, in spring, $88.2 \%$ autumn and $88.3 \%$ in summer. In winter, internal heat gain conditions $(61.8 \%)$ are highly influential in order to get comfort. Passive solar direct gain low mass $(20 \%)$ and elements of high thermal mass (18.5\%) are also the main strategies during this time of the year. A traditional action applied by users in winter is to expose the maximum glazed surface of balconies and courtyards during the day in order to accumulate the greatest disposal radiation and close most of the openings layers to reduce heat losses during the nighttime. Taking global warming into account, only modifying the solar exposure or wearing lightweight clothes would be sufficient to achieve comfort in this season. In summer conditions, comfort is even achieved during a large part of this season (56.1\%) without the use of any strategies. There is a greater interaction between the air inside and outside since the windows are opened during the night and the cooler hours of the day take advantage of radiant cooling and enhanced cross-ventilation (24\%). During the rest of the day, solar protections decrease part of the solar gain in openings (34.7\%). During this season, higher temperatures could reach temperatures of discomfort, which are palliated by means of enhancing the traditional methods to achieve comfort. 
Table 6. Design strategies for Cádiz. ASHRAE Comfort model 2005.

\begin{tabular}{lcccc}
\hline \multicolumn{1}{c}{ Design Strategies } & Winter & Spring & Summer & Autumn \\
\hline 1. Comfort & $2.6 \%$ & $37.5 \%$ & $56.1 \%$ & $21.3 \%$ \\
2. Sun shading of windows & $0.6 \%$ & $12.1 \%$ & $34.7 \%$ & $5.3 \%$ \\
3. High thermal mass & $0.0 \%$ & $2.0 \%$ & $7.8 \%$ & $1.1 \%$ \\
4. High thermal mass night flushed & $0.0 \%$ & $2.2 \%$ & $10.6 \%$ & $1.1 \%$ \\
5. Direct evaporative cooling & $0.0 \%$ & $2.3 \%$ & $6.9 \%$ & $0.8 \%$ \\
7. Natural ventilation cooling & $0.0 \%$ & $2.1 \%$ & $24.0 \%$ & $1.4 \%$ \\
9. Internal heat gain & $61.8 \%$ & $58.6 \%$ & $41.0 \%$ & $62.1 \%$ \\
10. Passive solar direct gain low mass & $20.0 \%$ & $12.4 \%$ & $0.0 \%$ & $12.1 \%$ \\
11. Passive solar direct gain high mass & $18.5 \%$ & $28.8 \%$ & $2.8 \%$ & $17.9 \%$ \\
Comfortable per cent hours using selected strategies & $74.9 \%$ & $99.4 \%$ & $88.3 \%$ & $88.2 \%$ \\
\hline
\end{tabular}

\subsection{Results}

Due to the qualitative analysis by the Adaptive Comfort Model applied to the climate of Cádiz, we identify that warmer months corresponding to summer outdoor conditions are close to the comfort standards, using natural ventilation as well as appropriate clothing for the occupants. To enhance the future climate adaptation, more strategies are needed. In cooler months, outdoor conditions stray far from the comfort standards. Therefore, historic dwellings need to adapt performance to ensure a comfortable shelter in the actual and future scenarios.

According to study conducted through the ASHRAE Handbook of Fundamentals Comfort Model 2005, in which climate responsive strategies applied to the historic dwellings can be analysed, comfort conditions can be achieved $87.7 \%$ of the year. During cooler months, solar heat gain is the more influential strategy applied, so an adequate use of clothing and dwelling openings achieve comfort for both actual and future climate conditions. On the other hand, during warmer months traditional cooling strategies can achieve comfort, although peak future temperatures could generate a slight discomfort. The key role of the user is the most important strategy during the whole year, which enhances the interaction between man, architecture and environment.

\section{Monitoring}

In order to analyse the indoor conditions in a quantitative manner, long-term monitoring has been established in winter and summer in a representative inhabited dwelling of medium height on the first storey. The selected indoor space is an inhabited bedroom in the first bay without any artificial means. Field measurements for winter were taken from the 10th to 20th of January 2011 and from the 7th to 17th July 2011 for summer (data loggers-HOBO RH/Temp/Light/External Data Logger, Austin, TX, USA). Temperature sensor accuracy is $\pm 0.7{ }^{\circ} \mathrm{C}$ and humidity sensor accuracy is $\pm 5.0 \% \mathrm{RH}$, respectively. The sensors are positioned in the center part of the room at 1 meter height.

In winter (Figure 7), indoor air temperature stays practically constant. During the 10 days measurement period, the room temperature was set close to $17{ }^{\circ} \mathrm{C}$ and $18{ }^{\circ} \mathrm{C}$ and the relative humidity indoors varies from $50 \%$ to $72 \%$ and its mean value is about $65 \%$. Due to the thermal inertia, internal heat gain and solar gain, indoor temperatures are far from outdoor conditions, storing heat gains. The action of the users, inhabiting the room and manipulating the main openings for a better solar exposure 
is crucial to maintain higher temperatures indoors. In addition, the attenuation of the thermal indoor wave determined experimentally plays a key role in this season, assuming a negligible effect from thermal lag. Despite the fact that the interior temperatures remain below the comfort limits, they are very close to these ones. Moreover, due to the temperature stability and greater tolerance of people who live in naturally ventilated buildings $[46,47]$, these conditions can be considered as permissible comfort. In future scenarios, certain increases of air temperature could be beneficial to achieve comfort during winter.

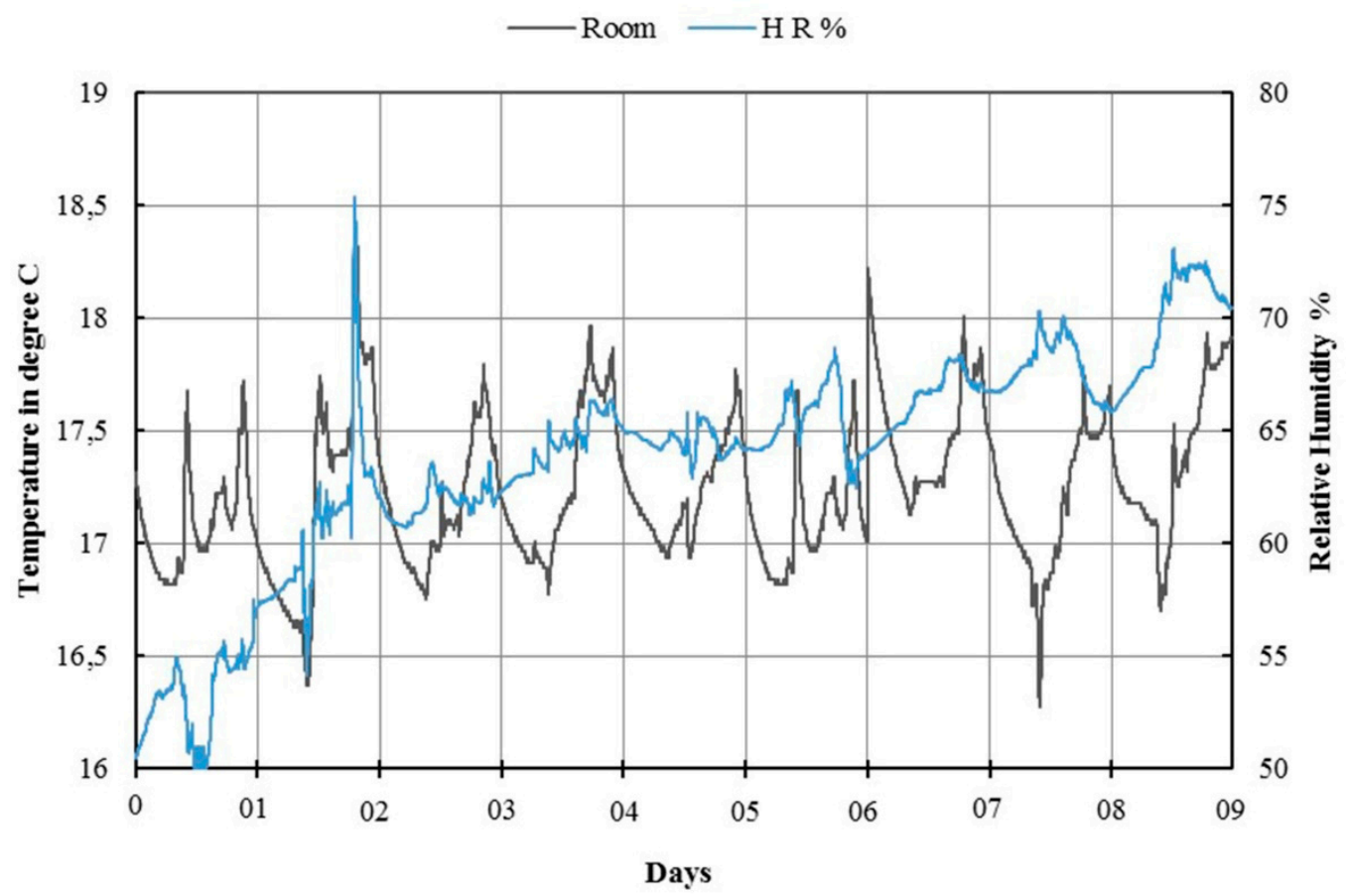

Figure 7. Temperature vs. Relative Humidity. Winter.

In the case of the measurements in summer conditions (Figure 8), it must be considered that the users applied various climate strategies: naturally ventilated interior spaces and modified solar protections in order to prevent excessive solar gains during a large part of the day. The interaction between the user and the environment through the architecture again modifies indoors conditions using traditional strategies to achieve comfort. Thermal inertia is influenced by the similar outdoor and indoor conditions, although during the nighttime, walls transmit gains indoors.

Considering data logger records, dwellings in the summer are set within the comfort limits thanks to the strategies applied, except minor fluctuations throughout the day that could be increasing in future scenarios. 


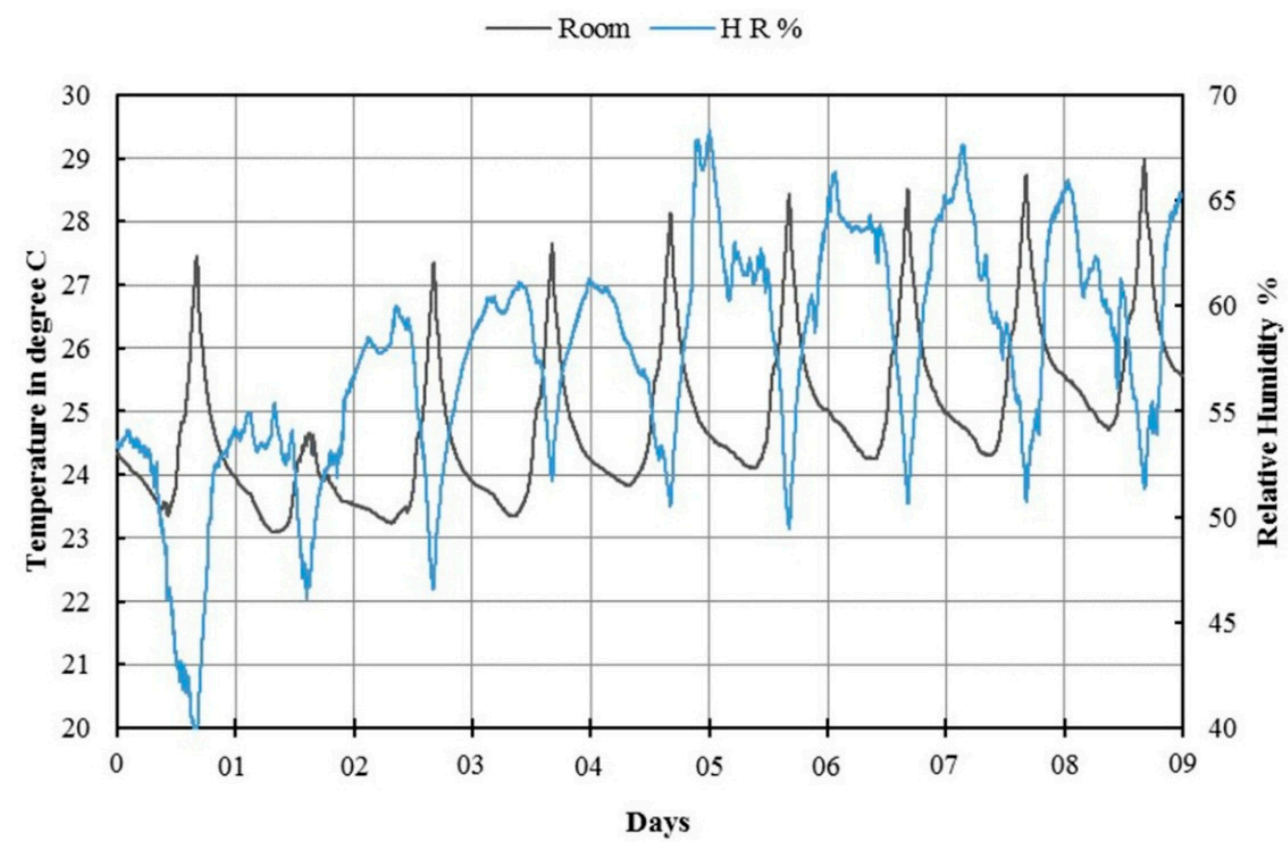

Figure 8. Temperature vs. Relative Humidity. Summer.

\section{Conclusions}

The results show that most of the architecture and urban grid correspond certainly with the strategies proposed by ASHRAE, considering that the mild climate has strengthened during history building environmental responsiveness, but there is a scope for improvements if global warming produces an increase in air temperature. Authors believe that knowledge will enhance urban retrofitting strategies centred on human comfort and environmentally conscious architectural design, although further research is needed to translate these traditional strategies into the modern context. In our study, we are in the position to assure that the most important design feature that should be preserved is not only tectonic, but aerial in both actual and future scenarios.

In this research, on-site measurements are useful to define the transient thermal behaviour of the inhabited dwellings, in which users adapt indoor conditions to an accurate range of comfort. As can be shown in this research, after manipulating the main openings for a better solar exposure in winter or using solar protection and natural ventilation methods in summer, a great influence in indoors conditions are produced.

Even if this study is strictly correlated to the intrinsic characteristics of Cádiz, the developed methodology highlights some conclusions that can give more general information on the climate adaptation and resilience of historic cities in the Mediterranean.

According to all information analysed in this paper, historic dwellings in the city of Cádiz can achieve comfort only by applying traditional strategies which do not require any air conditioning systems based on electricity consumption. In the next decades, it could be possible that they still elude the necessity to use electrical means. The constructive tradition of high mass in the façades and the accurate use of environmental control systems in openings favour comfort in the coming years. 


\section{Acknowledgments}

The authors extend sincere gratitude to the General Urban Development Plan Office of Cádiz for the support of the fieldwork research. The authors also extend sincere gratitude to the Department of Architecture and Urban Design of the University of California for the Climate Consultant tool.

\section{Author Contributions}

All authors contributed equally to this work. Carlos Rubio-Bellido conceived and drafted the paper; Jesus A. Pulido-Arcas and Jose M. Cabeza-Lainez analyzed the data and reviewed related studies. All authors wrote, reviewed and commented on the manuscript. All authors have read and approved the final manuscript.

\section{Conflicts of Interest}

The authors declare no conflict of interest.

\section{References}

1. Crawley, D.B. Estimating the impacts of climate change and urbanization on building performance. J. Build. Perform. Simul. 2008, 1, 91-115.

2. Robert, A.; Kummert, M. Designing net-zero energy buildings for the future climate, not for the past. Build. Environ. 2012, 55, 150-158.

3. Groot, A.M.E.; Bosch, P.R.; Buijs, S.; Jacobs, C.M.J.; Moors, E.J. Integration in urban climate adaptation: Lessons from Rotterdam on integration between scientific disciplines and integration between scientific and stakeholder knowledge. Build. Environ. 2015, 83, 177-188.

4. Van Hooff, T.; Blocken, B.; Hensen, J.L.M.; Timmermans, H.J.P. Reprint of: On the predicted effectiveness of climate adaptation measures for residential buildings. Build. Environ. 2015, 83, 142-158.

5. Lomas, K.J.; Giridharan, R. Thermal comfort standards, measured internal temperatures and thermal resilience to climate change of free-running buildings: A case-study of hospital wards. Build. Environ. 2012, 55, 57-72.

6. Mavrogianni, A.; Wilkinson, P.; Davies, M.; Biddulph, P.; Oikonomou, E. Building characteristics as determinants of propensity to high indoor summer temperatures in London dwellings. Build. Environ. 2012, 55, 117-130.

7. European Commission. EU Energy in Figures-Statistical Pocketbook 2013; Publications Office of the European Union: Luxembourg, 2013.

8. Government of Spain. Energy Saving and Efficiency Action Plan 2011-2020; Spanish Institute for Energy Diversification and Saving: Madrid, Spain, 2011.

9. Solomon, S. Climate Change 2007: The Physical Science Basis; Cambridge University Press: Cambridge, UK, 2007.

10. Coley, D.A. Energy and Climate Change; Wiley-Blackwell: Hoboken, NJ, USA, 2008.

11. Schiermeier, Q. The real holes in climate science. Nature 2010, 463, 284-287. 
12. Oktay, D. Design with the climate in housing environments: An analysis in Northern Cyprus. Build. Environ. 2002, 37, 1003-1012.

13. Kruger, E.; Cruz, E.G.; Givoni, B. Effectiveness of indirect evaporative cooling and thermal mass in a hot arid climate. Build. Environ. 2010, 45, 1422-1433.

14. Barbero-Barrera, M.M.; Gil-Crespo, I.J.; Maldonado-Ramos, L. Historical development and environment adaptation of the traditional cave-dwellings in Tajuña's valley, Madrid, Spain. Build. Environ. 2014, 82, 536-545.

15. Dili, A.S.; Naseer, M.A.; Varghese, T.Z. Passive environment control system of Kerala vernacular residential architecture for a comfortable indoor environment: A qualitative and quantitative analyses. Energy Build. 2010, 42, 917-927.

16. Lin, B.; Tan, G.; Wang, P.; Ling, S.; Zhu, Y.; Zhai, G. Study on the thermal performance of the Chinese traditional vernacular dwellings in Summer. Energy Build. 2004, 36, 73-79.

17. Supic, P. Vernacular architecture: A lesson of the past for the future. Energy Build. 1982, 5, 43-54.

18. Cañas, I.; Martín, S. Recovery of Spanish vernacular construction as a model of bioclimatic architecture. Build. Environ. 2004, 39, 1477-1495.

19. Cabeza-Lainez, J.M. Lighting Features in Japanese Traditional Architecture. In Lessons from Vernacular Architecture; Routledge: London, UK, 2013; pp. 143-154.

20. Van Hoof, J. Forty years of Fanger's model of thermal comfort: Comfort for all? Indoor Air 2008, $18,182-201$.

21. Humphreys, M.; Nicol, J. Outdoor Temperature and indoor thermal comfort: Raising the precision of the relationship for the 1998 ASHRAE database of Field Studies. AHSRAE Trans. 2000, 206, 485-492.

22. AHSRAE Standards Committee. Thermal Environmental Conditions for Human Occupancy; American Society of Heating, Refrigerating and Air-conditioning: Atlanta, GA, USA, 2004.

23. AHSRAE Technical Committes. 2005 ASHRAE Handbook of Fundamentals; American Society of Heating, Refrigerating and Air-conditioning: Atlanta, GA, USA, 2005; pp. 636-840.

24. Climate Consultant 5.5. Energy Design Tool, UCLA. Available online: http://www.energydesign-tools.aud.ucla.edu/ (accessed on 3 February 2015).

25. EPW Weather data, U.S. Department of Energy. Available online: http://apps1.eere.energy.gov/ buildings/energyplus/weatherdata_about.cfm (accessed on 3 February 2015).

26. Rubio-Bellido, C.; Pantión, R.L.; Pérez, P.G. The future of fortifications in the city of Cádiz: Opportunities and strategies for an urban regeneration. WIT Trans. Built Environ. 2011, 123, 135-147.

27. Falcón, T. Iconografía: territorio y ciudad en el Cádiz del S. XVI. Trocadero, Revista de Historia Moderna y Contemporánea 2003, 16, 501-506. (In Spanish)

28. De la Flor, F.J.S.; Domínguez, S.Á.; Félix, J.L.M.; Falcón, R.G. Climatic zoning and its application to Spanish building energy performance regulations. Energy Build. 2008, 40, 1984-1990.

29. Rubio-Bellido, C.; Sanchez-Montañes, B.; Pulido-Arcas, J.A.; Cabeza-Lainez, J.M. Techniques of environmental analysis applied to the urban heritage of Cádiz. In Proceedings of the 3rd International Conference on Heritage and Sustainable Environment, Proto, Portugal, 19-22 June 2012.

30. AEMET, Agencia Estatal de Meteorología, Ministerio de Agricultura, Alimentación y Medio Ambiente, Gobierno de España. Avaliable online: http://www.aemet.es/ (accessed on 3 February 2015). 
31. Catálogo de patrimonio arquitectónico. Plan General de Ordenación Urbana de Cádiz 2012. Avaliable online: http://institucional.Cádiz.es/area/Urbanismo/57 (accessed on 3 February 2015).

32. Sanchez-Montañes, B.; Rubio-Bellido, C.; Pulido-Arcas, J.A. Passive solar gains in the urban grid of the historic city: The case study of Cádiz. In Proceedings of the International Conference Energy Efficiency in Historic Buildings, Madrid, Spain, 13 May 2014.

33. Sanchez-Montañes, B.; Cabeza-Lainez, J.M. Daylight in Historical Centres: The case of an architect's office in Seville. In Proceedings of the Passive \& Low Energy Architecture, Singapore, 12 November 2007; Department of Architecture, School of Design and Environment, National Univesity of Singapore: Singapore; pp. 447-449.

34. Andreou, E. The effect of urban layout, street geometry and orientation on shading conditions in urban canyons in the Mediterranean. Renew. Energy 2014, 63, 587-596.

35. Cabeza-Lainez, J.M. Fundamentos de Transferencia Radiante Luminosa; Including software for simulation; Netbiblo: La Coruña, Spain, 2010.

36. Cabeza-Lainez, J.M. Solar radiation in buildings, transfer and simulation procedures. Solar Radiat. 2012, doi:10.5772/33978.

37. International Organization for Standardization (ISO). Building Components and Building Elements, Thermal Resistance and Thermal Transmittance, Calculation Method; ISO: Geneva, Switzerland, 2007.

38. International Organization for Standardization (ISO). Thermal Performance of Building Components, Dynamic Thermal Characteristics, Calculation Methods; ISO: Geneva, Switzerland, 2007.

39. Aste, N.; Angelotti, A.; Buzzetti, M. The influence of the external walls thermal inertia on the energy performance of well insulated buildings. Energy Build. 2009, 41, 1181-1187.

40. Gagliano, A.; Patania, F.; Nocera, F.; Signorello, C. Assessment of the dynamic thermal performance of massive buildings. Energy Build. 2014, 72, 361-370.

41. International Organization for Standardization (ISO). Thermal Performance of Windows, Doors and Shutters. Calculation of Thermal Transmittance, Part 1: General; ISO: Geneva, Switzerland, 2006.

42. Ministerio de Fomento Secretaría de Estado de Infraestructuras, Transporte y Vivienda Dirección General de Arquitectura, Vivienda y Suelo. DA DB-HE/1:2013 Cálculo de parámetros característicos de la envolvente. In Documento de Apoyo al Documento Básico DB-HE Ahorro de energía Código Técnico de la Edificación; Ministerio de Fomento: Madrid, España, 2013.

43. De Lama, J.P.; Cabeza-Lainez, J.M. The patio: a constant in Mediterranean architecture; climate and symbolism. In Proceedings of Passive \& Low Energy Architecture, Sevilla, Spain, 30 September 1991; Kluwer Academic Publishers: Seville, Spain; pp. 269-274.

44. Safarzadeh, H.; Bahador, M.N. Passive cooling effects of courtyards. Build. Environ. 2005, 40, 89-104.

45. Abdelsalam, A. Thermal performance of courtyard buildings. Energy Build. 2008, 40, 906-910.

46. Feriadi, H.; Wong, N.H. Thermal comfort for naturally ventilated houses in Indonesia. Energy Build. 2004, 36, 614-626. 
47. Bouden, C.; Ghrab, N. An adaptive thermal comfort model for the Tunisian context: A field study results. Energy Build. 2005, 37, 952-963.

(C) 2015 by the authors; licensee MDPI, Basel, Switzerland. This article is an open access article distributed under the terms and conditions of the Creative Commons Attribution license (http://creativecommons.org/licenses/by/4.0/). 